\title{
An Unusual Case of Campylobacter jejuni Gastroenteritis Presenting with Acute Reversible Encephalopathy in an Immunocompetent Host
}

\author{
Irma Huayanay $\mathbb{D}^{1,2,3}$ Leonardo Pozo, ${ }^{1,2,3}$ Salman Bangash, ${ }^{1,2,3}$ Denisse Ramirez, ${ }^{1,2,3}$ \\ Luis Rosas, ${ }^{3,4}$ and Renzo Arauco Brown ${ }^{3,5}$ \\ ${ }^{1}$ School of Medicine, The University of Texas Rio Grande Valley, Edinburg, Texas, USA \\ ${ }^{2}$ Internal Medicine Residency Program, University of Texas Rio Grande Valley, Edinburg, Texas, USA \\ ${ }^{3}$ Doctors Hospital at Renaissance, Edinburg, Texas, USA \\ ${ }^{4}$ South Texas Infectious Disease Consultants, McAllen, Texas, USA \\ ${ }^{5}$ Pulmonary and Sleep Center of the Valley, McAllen, Texas, USA
}

Correspondence should be addressed to Irma Huayanay; irma.huayanayespinoza@utrgv.edu

Received 2 January 2020; Revised 21 March 2020; Accepted 19 June 2020; Published 6 July 2020

Academic Editor: Gernot Walder

Copyright (c) 2020 Irma Huayanay et al. This is an open access article distributed under the Creative Commons Attribution License, which permits unrestricted use, distribution, and reproduction in any medium, provided the original work is properly cited.

\begin{abstract}
Campylobacter jejuni gastroenteritis is the most frequent organism associated with acute infectious diarrhea worldwide. The clinical presentation involves fever, diarrhea, rigors, and myalgias. Other extraintestinal symptoms that have been described involve delirium and other neurological complications, and the most well-known is Guillain-Barré, where there is cross-reactivity between the gastrointestinal tract and the brain. Despite previously described multiple neurological complications, there is a lack of clinical data on the association of Campylobacter-related gastroenteritis with acute encephalopathy in immunocompetent patients. The type of population, immunocompetent stage, and unfamiliarity with the clinical presentation makes this a challenging diagnosis for clinicians. We report a case of Campylobacter gastroenteritis associated with acute encephalopathy in an immunocompetent patient.
\end{abstract}

\section{Introduction}

Campylobacter jejuni (C. jejuni) is the most frequent organism associated with acute bacterial gastroenteritis around the world [1]. The high incidence of Campylobacter diarrhea, as well as its duration and possible complications, makes it highly important from a socioeconomic perspective [2]. It is estimated to cause 1.3 million human illnesses every year with 96 million cases in 2010 in the United States [3]. The clinical presentation is characterized mainly by abdominal pain and diarrhea. A prodrome phase characterized by fever, rigors, myalgias, and occasional delirium has been described [2]. The most well-known postinfectious neurological complications are Guillain-Barré syndrome (GBS) and Miller-Fisher syndrome (MFS) [4]. Furthermore, worldwide the incidence is 1 to 2 in 100,000 and 1 to 2 in $1,000,000$, for GBS and MFS, respectively [5]. Nearly $30-40 \%$ of GBS patients had C. jejuni infection 2 weeks prior to onset of neurological symptoms [6]. Other less frequent neurological complications include Bickerstaff's brainstem encephalitis, acute transverse myelitis, and acute disseminated encephalomyelitis (ADEM) [4, 7-9]. We present a case of Campylobacter gastroenteritis presenting with associated encephalopathy in an immunocompetent patient.

\section{Case}

A twenty-five-year-old female with unremarkable past medical history was brought to the emergency department due to progressive altered mental status. Per family report, 
the patient was in her usual state of health until one week before this admission when she started to experience abdominal pain and diarrhea. The patient's mother described episodes of anxiety and unusual behavior-associated confusion specially the day before admission.

On the day of admission, the patient sought medical attention at an outpatient clinic. While in the office, she became confused and later she experienced a witnessed seizure. The patient received a dose of lorazepam prior to arrival at the hospital. On arrival to the emergency department, she was found unresponsive with a Glasgow Coma Scale of six. She was afebrile and tachycardic with a heart rate of 115 beats per minute. The rest of her vital signs were within normal limits.

Her physical exam was remarkable for generalized decreased muscle tone and no clear focal deficits. The patient was intubated for airway protection. She was given a loading dose of levetiracetam and was admitted to the neurosciences intensive care unit.

Her initial laboratory tests showed respiratory alkalosis with an elevated white blood cell count at 11.6 th $/ \mu$ l with $76.5 \%$ of neutrophils. Her complete metabolic panel showed hypokalemia. Her urine toxicology, serum alcohol levels, and urine analysis were unremarkable. $C$-reactive protein was $3.3 \mathrm{mg} / \mathrm{dL}$, and her lactic acid was $1.2 \mathrm{mmol} / \mathrm{L}$. Blood tests are summarized in Table 1.

A brain computed tomography (CT) without contrast showed slightly increased low density in the left occipital white matter compared to the right which increased the suspicion of posterior reversible encephalopathy syndrome (PRES), and these images are shown in Figure 1. Herpes simplex virus (HSV) encephalitis and autoimmune epilepsy were also considered in the differential diagnosis. The brain $\mathrm{CT}$ with perfusion was negative for stroke. Chest X-ray showed atelectatic changes in the right upper lobe. A CT of the abdomen and pelvis was negative for ovarian teratoma. The patient was started on acyclovir for suspected herpetic encephalitis.

A brain magnetic resonance (MRI) was negative for findings supporting the diagnosis of PRES. The electroencephalogram showed no evidence of seizure activity or epileptiform discharges. Lumbar puncture was performed, and the cerebrospinal fluid (CSF) had a clear appearance. The opening pressure was normal. The CSF glucose was elevated at 91 units. The CSF white blood cell count was $3 / \mu \mathrm{L}$. Further studies on CSF for ruling out meningitis were done, and they included Cryptococcus neoformans/gattii, Cytomegalovirus, Enterovirus CSF, E. coli K1, Hemophilus influenzae, Human Parechovirus, Listeria monocytogenes, Neisseria meningitidis, Streptococcus agalactiae, Streptococcus pneumoniae, varicellazoster, and herpes simplex virus 1, 2, and 6, which were negative; details are shown in Table 2.

The infectious disease team was consulted, and doxycycline was added due to the high prevalence of typhus in the area. Febrile agglutinins, West Nile virus, and fungal serologies were also negative (Table 1).

CSF studies for autoimmune epilepsy, including $\mathrm{N}$-methyl-D-aspartate (NMDA) receptor antibodies, glutamic acid decarboxylase (GAD-65) antibodies, and voltage- gated potassium channel (VGKC) antibodies, were negative for autoimmune epilepsy, the more detailed studies in Table 2. Human immunodeficiency virus was negative. Autoimmune panel was negative for antineutrophil cytoplasmic antibodies (ANCAs), antinuclear antibody (ANA), and double stranded DNA (dsDNA) antibodies.

Due to persistent diarrhea during the initial day of admission, a gastrointestinal infectious panel was ordered and was positive for C. jejuni (Table 3).

Based on the clinical scenario of a patient with extraintestinal complications of Campylobacter infection, it was decided to start azithromycin $500 \mathrm{mg}$ per mouth for at least 10 days. The patient showed significant improvement after the first dose and recovered over the next few days prior to discharge.

\section{Discussion}

We are describing a case of Campylobacter jejuni gastroenteritis associated with acute encephalopathy in an immunocompetent adult. The complex initial presentation with neurological symptoms makes this clinical scenario a diagnostic challenge due to the unfamiliarity of clinicians with this disease.

Campylobacter species belongs to a distinct group of specialized Gram-negative bacteria designated as rRNA superfamily VI [10]. The most important species that can cause human disease are C. jejuni and C. coli [11]. Campylobacters invade the intestinal epithelium using flagella, high molecular weight plasmids, superficial adhesins, and chemotactic factors [12].

Patients infected with C. jejuni gastroenteritis experience acute watery or bloody diarrhea, fever, weight loss, and cramps that last six days on average [11]. Besides the gastrointestinal local infection, Campylobacter species also can cause a range of other clinical manifestations or postinfectious immune disorders [13].

While infection with C. jejuni can occur in patients of all ages, this infection is more prevalent in toddlers and young adults than in other age groups [14]. Despite most of the neurologic complications associated with Campylobacter enteritis have been historically linked to the pediatric population, some of these manifestations have been also described in adults [9].

Our patient had an unusual presentation of C. jejuni gastroenteritis associated with acute encephalopathy. Based on her initial symptoms, she was treated with acyclovir for the suspicion of HSV encephalitis. Moreover, the combination of seizures in association with the abnormalities noted in the mentioned neuroimaging raised the initial suspicion for PRES and autoimmune epilepsy. These diagnoses were ruled out with a brain MRI and a CSF autoimmune panel, respectively [15-17].

Other autoimmune systemic diseases including lupus and vasculitis were ruled out with negative ANCA, ANA, and dsDNA. We also considered ADEM following a C. jejuni gastroenteritis in our differential diagnosis. Nonetheless, the MRI did not show increased T2-signal intensity in the white matter which is a characteristic neuroimaging finding in 
TABLE 1: Blood studies.

\begin{tabular}{|c|c|c|c|}
\hline & Blood analysis & Result & Reference range \\
\hline \multirow{15}{*}{ Complete blood count } & White blood cell & 11.6 & $(4.8-10.9)$ th $/ \mu \mathrm{L}$ \\
\hline & Percent neutrophils & 76.5 & $(49.0-77.6) \%$ \\
\hline & Percent lymphocytes & 17.7 & $(11.8-40.8) \%$ \\
\hline & Percent monocytes & 5 & $(3.70-11.80) \%$ \\
\hline & Percent eosinophils & 0.2 & $(0-4.8) \%$ \\
\hline & Percent basophils & 0.3 & $(0-1.3) \%$ \\
\hline & Percent immature granulocytes & 0.3 & $(0-1) \%$ \\
\hline & Hemoglobin & 12.6 & $(10.8-14.7) \mathrm{gm} / \mathrm{dL}$ \\
\hline & Hematocrit & 36.8 & $(32.2-42.9) \%$ \\
\hline & Mean corpuscular volume & 87.4 & $(84-96) \mathrm{fL}$ \\
\hline & Mean corpuscular hemoglobin & 29.9 & $(28.3-32.3) \mathrm{pg}$ \\
\hline & Mean corpuscular hemoglobin concentration & 34.2 & $(29.58-33.75) \mathrm{gm} / \mathrm{dL}$ \\
\hline & Platelet count & 212 & $(146-388) \mathrm{th} / \mu \mathrm{L}$ \\
\hline & Red blood cell distribution width CV & 12 & $(12.20-15.80) \%$ \\
\hline & Red blood cell distribution width SD & 38.6 & $(38.93-51.44) \mathrm{fL}$ \\
\hline \multirow{14}{*}{ Complete metabolic panel } & Sodium & 136 & $(132-143) \mathrm{mmol} / \mathrm{L}$ \\
\hline & Potassium & 3.3 & $(3.5-5.1) \mathrm{mmol} / \mathrm{L}$ \\
\hline & Chloride & 105 & $(98-107) \mathrm{mmol} / \mathrm{L}$ \\
\hline & Carbon dioxide & 23 & $(21-31) \mathrm{mmol} / \mathrm{L}$ \\
\hline & Creatinine & 0.7 & $(0.6-1.2) \mathrm{mg} / \mathrm{dL}$ \\
\hline & BUN & 12 & $(7-25) \mathrm{mg} / \mathrm{dL}$ \\
\hline & Calcium & 8.8 & $(8.6-10.3) \mathrm{mg} / \mathrm{dL}$ \\
\hline & Glucose & 119 & $(70-113) \mathrm{mg} / \mathrm{dL}$ \\
\hline & Ammonia & 30 & $(16-53) \mathrm{umol} / \mathrm{L}$ \\
\hline & AST & 17 & $(13-39) \mathrm{IU} / \mathrm{L}$ \\
\hline & ALT & 15 & $(7-52) \mathrm{IU} / \mathrm{L}$ \\
\hline & Alkaline phosphatase & 73 & $(34-104) \mathrm{IU} / \mathrm{L}$ \\
\hline & Albumin & 4.1 & $(3.7-4.9) \mathrm{gm} / \mathrm{dL}$ \\
\hline & Total bilirubin & 0.3 & $(0.2-1.2) \mathrm{mg} / \mathrm{dL}$ \\
\hline \multirow{3}{*}{ Coagulation studies } & PT & 12.9 & (10.6-13) second \\
\hline & INR & 1.11 & $(0.90-1.10)$ INR \\
\hline & PTT & 22.8 & (24-36.7) second \\
\hline \multirow{5}{*}{ Others } & Sedimentation rate & 46 & $2-30 \mathrm{~mm} / \mathrm{hr}$ \\
\hline & C-reactive protein & 3.3 & $<1 \mathrm{mg} / \mathrm{dL}$ \\
\hline & Lactic acid & 1.2 & $(0.5-1.99) \mathrm{mmol} / \mathrm{L}$ \\
\hline & Alcohol serum & $<10.00$ & $<10.00 \mathrm{mg} / \mathrm{dL}$ \\
\hline & Alcohol serum calculation & $<0.01$ & $<0.01 \mathrm{gm} / \mathrm{dL}$ \\
\hline \multirow{6}{*}{ Serology } & ANCA screen* & Negative & Negative \\
\hline & dsDNA & 1.5 & $<10 \mathrm{IU} / \mathrm{mL}$ \\
\hline & Symphony ANA screen & 0.1 & $<0.7$ ratio \\
\hline & Symphony ANA & 0.2 & $<0.7$ ratio \\
\hline & Complement C3 & 156 & $(87-200) \mathrm{mg} / \mathrm{dL}$ \\
\hline & Complement C4 & 26 & $(19-52) \mathrm{mg} / \mathrm{dL}$ \\
\hline \multirow{9}{*}{ Infectious studies } & HIV antibodies & Nonreactive & Nonreactive \\
\hline & Aspergillus flavus antibody & Negative & Negative \\
\hline & Aspergillus niger antibody & Negative & Negative \\
\hline & Aspergillus fumigatus antibody & Negative & Negative \\
\hline & Coccidioides antibody & Negative & Negative \\
\hline & Histoplasma antibody & Negative & Negative \\
\hline & Blastomycosis antibody & Negative & Negative \\
\hline & Febrile agglutinin panel ${ }^{*}$ & Negative & Negative \\
\hline & Respiratory viral panel $\mathrm{PCR}^{*}$ & Negative & Negative \\
\hline
\end{tabular}

*ANCA screen: p-ANCA, c-ANCA, and atypical p-ANCA. *Febrile agglutinin panel: P-OX19, POX2, P-OXK, and Brucella. * Respiratory viral panel includes adenovirus, coronavirus, influenza A, influenza B, human metapneumovirus, parainfluenza, respiratory syncytial virus, rhinovirus, Enterovirus, Bordetella pertussis, Chlamydophila pneumoniae, and Mycoplasma pneumoniae.

ADEM [4]. Furthermore, patients suffering ADEM only improve with high-dose steroids that our patient never received [4].
Based on Rio Grande Valley demographics with high prevalence of murine typhus in the area, the patient was treated empirically with doxycycline until her agglutinins 


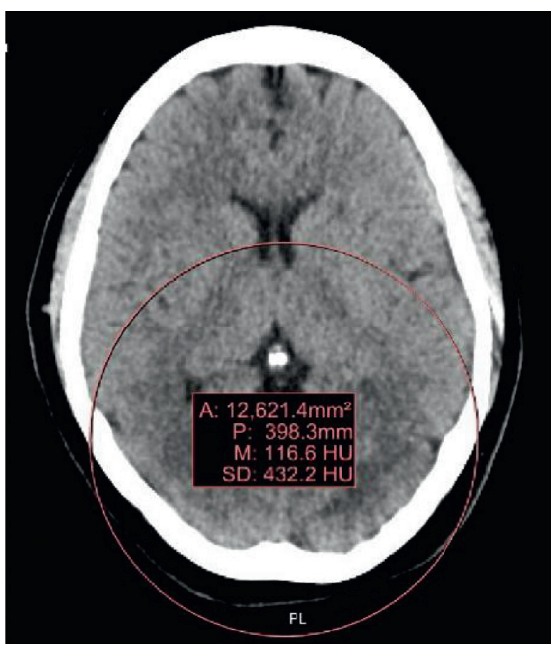

(a)

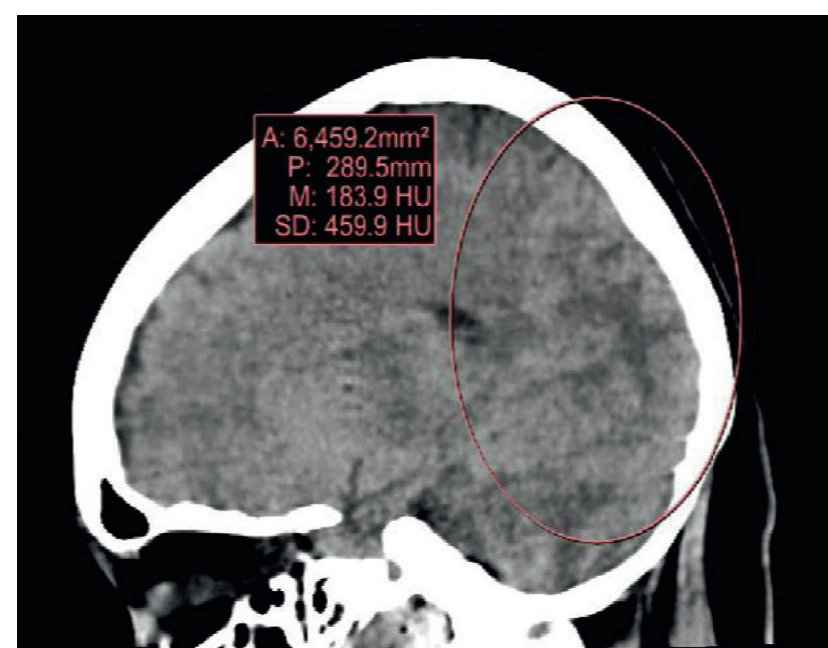

(b)

FIGURE 1: CT head without contrast showing increased low density in the left occipital white matter.

TABLE 2: CSF studies.

\begin{tabular}{|c|c|c|c|}
\hline & Variable & Result & Reference range \\
\hline \multirow{5}{*}{ General analysis } & CSF appearance & Clear & Clear \\
\hline & CSF WBC & 3 & $0-5 / \mu \mathrm{L}$ \\
\hline & CSF RBC & 0 & $0 / \mu \mathrm{L}$ \\
\hline & CSF glucose & 91 & $40-70 \mathrm{mg} / \mathrm{dL}$ \\
\hline & CSF total protein & 26 & $15-45 \mathrm{mg} / \mathrm{dL}$ \\
\hline \multirow{16}{*}{ Infectious studies } & CSF Cryptococcus neoformans/gattii antigen & Not detected & Not detected \\
\hline & CSF Cytomegalovirus & Not detected & Not detected \\
\hline & CSF Enterovirus & Not detected & Not detected \\
\hline & CSF Escherichia coli $\mathrm{K} 1$ & Not detected & Not detected \\
\hline & CSF Hemophilus influenzae & Not detected & Not detected \\
\hline & CSF herpes simplex virus 1 & Not detected & Not detected \\
\hline & CSF herpes simplex virus 2 & Not detected & Not detected \\
\hline & CSF human herpes virus 6 & Not detected & Not detected \\
\hline & CSF human Parechovirus & Not detected & Not detected \\
\hline & CSF Listeria monocytogenes & Not detected & Not detected \\
\hline & Neisseria meningitidis & Not detected & Not detected \\
\hline & Streptococcus agalactiae & Not detected & Not detected \\
\hline & Streptococcus pneumoniae & Not detected & Not detected \\
\hline & Varicella-zoster virus & Not detected & Not detected \\
\hline & CSF West Nile IgM & $<0.90$ & $<0.90$ \\
\hline & CSF culture & No growth & No growth \\
\hline \multirow{9}{*}{ Autoimmune studies } & CSF VGKC antibody & $<20$ & $<20 \mathrm{pmol} / \mathrm{L}$ \\
\hline & CSF NMDA receptor antibody & Negative & Negative \\
\hline & CSF NMDAR1 antibody, CBA & Negative & Negative \\
\hline & CSF AMPAR1 antibody, CBA & Negative & Negative \\
\hline & CSF AMPAR2 antibody, CBA & Negative & Negative \\
\hline & GABABR antibody, CBA & Negative & Negative \\
\hline & LGI1 antibody, CBA & Negative & Negative \\
\hline & CASPR2 antibody, CBA & Negative & Negative \\
\hline & GAD-65 & $<5$ & $<5 \mathrm{IU} / \mathrm{mL}$ \\
\hline
\end{tabular}

VGKC: voltage-gated potassium channel; NMDA: N-methyl-D-aspartate; AMPAR: alpha-amino-3-hydroxy-5-methyl-4-isoxazolepropionate receptor; GABA: gamma aminobutyric acid B receptor; LGI1: leucine-rich glioma-inactivated 1; CASPR2: contactin-associated protein 2; GAD: glutamic acid decarboxylase. 
TABle 3: Stool studies.

\begin{tabular}{|c|c|c|c|}
\hline & Variable & Result & Reference range \\
\hline Gastrointestinal analysis & $\begin{array}{c}\text { Campylobacter } \\
\text { Clostridium difficile } \\
\text { Plesiomonas shigelloides } \\
\text { Salmonella } \\
\text { Yersinia enterocolitica } \\
\text { Vibrio } \\
\text { Vibrio cholerae } \\
\text { Enteroaggregative E. coli } \\
\text { Enteropathogenic E. coli } \\
\text { Enterotoxigenic E. coli } \\
\text { Shiga-like toxin-producing E. coli } \\
\text { E. coli O157 } \\
\text { Shigella/enteroinvasive E. coli } \\
\text { Cryptosporidium } \\
\text { Cyclospora cayetanensis } \\
\text { Entamoeba histolytica } \\
\text { Giardia lamblia } \\
\text { Adenovirus } \\
\text { Astrovirus } \\
\text { Norovirus } \\
\text { Rotavirus } \\
\text { Sapovirus }\end{array}$ & $\begin{array}{l}\text { Detected } \\
\text { Not detected } \\
\text { Not detected } \\
\text { Not detected } \\
\text { Not detected } \\
\text { Not detected } \\
\text { Not detected } \\
\text { Not detected } \\
\text { Not detected } \\
\text { Not detected } \\
\text { Not detected } \\
\text { Not detected } \\
\text { Not detected } \\
\text { Not detected } \\
\text { Not detected } \\
\text { Not detected } \\
\text { Not detected } \\
\text { Not detected } \\
\text { Not detected } \\
\text { Not detected } \\
\text { Not detected } \\
\text { Not detected }\end{array}$ & $\begin{array}{l}\text { Not detected } \\
\text { Not detected } \\
\text { Not detected } \\
\text { Not detected } \\
\text { Not detected } \\
\text { Not detected } \\
\text { Not detected } \\
\text { Not detected } \\
\text { Not detected } \\
\text { Not detected } \\
\text { Not detected } \\
\text { Not detected } \\
\text { Not detected } \\
\text { Not detected } \\
\text { Not detected } \\
\text { Not detected } \\
\text { Not detected } \\
\text { Not detected } \\
\text { Not detected } \\
\text { Not detected } \\
\text { Not detected } \\
\text { Not detected }\end{array}$ \\
\hline
\end{tabular}

were negative [18]. In this clinical case, the neurological and gastrointestinal symptoms rapidly resolved once the patient was started on azithromycin for Campylobacter gastroenteritis. Azithromycin is the antibiotic of choice, has good coverage for Campylobacter jejuni, shortens the duration of symptoms, and decreases resistance compared to fluoroquinolones $[19,20]$.

At this present time, the exact pathophysiology of Campylobacter gastroenteritis associated with encephalopathy is unknown, but it is possible that mechanisms involving antibody cross-reactivity may play a role [9]. For example, it is well known that bidirectional signaling exists between the gastrointestinal tract and the brain in GuillainBarré syndrome after a $C$. jejuni infection, where the outer membrane structures of Campylobacter containing sialic acid resemble those seen in the human gangliosides [9].This brings the topic of gut-brain axis, which explains that everything is interconnected: the gut can influence the brain, the brain can influence the gut, and they both can influence and be influenced by the immune system [21].

There are only a few cases of Campylobacter gastroenteritis with encephalopathy in immunocompetent population, and one of them went through a similar analysis process of differential diagnoses, obtained similar workup as in our patient based on the neurological symptoms, age of the patient, immunocompetent status, and severity of symptoms onset, with clinical improvement after starting antibiotics [9].

Due to the low prevalence of Campylobacter-associated encephalopathy in adults, we do not recommend assuming that mental status changes in a patient presenting with Campylobacter gastroenteritis are necessarily associated with the infection. A proper and well-directed workup should be completed to rule out other more frequent and emergent neurological diseases such as bacterial meningitis or vascular disease. We would recommend considering Campylobacterassociated encephalopathy in the differential diagnosis of diarrhea associated with mental status changes.

\section{Conflicts of Interest}

The authors declare that they have no conflicts of interest.

\section{References}

[1] B. M. Allos, "Campylobacter jejuni Infections: update on emerging issues and trends," Clinical Infectious Diseases: An Official Publication of the Infectious Diseases Society of America, vol. 32, no. 8, pp. 1201-1206, 2001.

[2] World Health Organization, "Campylobacter World Health Organization newsroom," 2018, https:/www.who.int/newsroom/fact-sheets/detail/campylobacter.

[3] Centers for Disease Control and Prevention, CDC Yellow Book 2020: Health Information for International Travel, Oxford University Press, New York, NY, USA, 2017.

[4] S. Marziali, E. Picchi, F. Di Giuliano et al., "Acute disseminated encephalomyelitis following Campylobacter jejuni gastroenteritis: case report and review of the literature," The Neuroradiology Journal, vol. 30, no. 1, pp. 65-70, 2017.

[5] F. Rocha Cabrero and E. H. Morrison, Miller Fisher Syndrome, StatPearls Publishing, Treasure Island, FL, USA, 2020, https:// www.ncbi.nlm.nih.gov/books/NBK507717/.

[6] B. M. Allos, "Association between Campylobacter Infection and Guillain-Barré syndrome," The Journal of Infectious Diseases, vol. 176, no. s2, pp. S125-S128, 1997.

[7] I. Levy, Y. Weissman, Y. Sivan, J. Ben-Ari, and T. Scheinfeld, "Acute encephalopathy associated with Campylobacter enteritis," BMJ, vol. 293, no. 6544, p. 424, 1986.

[8] R. A. Van der Kruijk, M. J. Affourtit, H. P. Endtz, and W. F. M. Arts, "Campylobacter jejuni gastroenteritis and acute 
encephalopathy," Journal of Infection, vol. 28, no. 1, pp. 99-100, 1994.

[9] D. Lepur, V. Peterković, S. B. Kovačević, K. Višković, N. K. Lepur, and M. Kutleša, "Acute encephalopathy associated with Campylobacter jejuni enteritis," Neurological Sciences, vol. 33, no. 1, pp. 155-158, 2012.

[10] P. Vandamme, E. Falsen, R. Rossau et al., "Revision of Campylobacter, Helicobacter, and Wolinella taxonomy: emendation of generic descriptions and proposal of Arcobacter gen. nov," International Journal of Systematic Bacteriology, vol. 41, no. 1, pp. 88-103, 1991.

[11] S. M. Man, "The clinical importance of emerging Campylobacter species," Nature Reviews Gastroenterology \& Hepatology, vol. 8, no. 12, pp. 669-685, 2011.

[12] T. M. Wassenaar and M. J. Blaser, "Pathophysiology of Campylobacter jejuni infections of humans," Microbes and Infection, vol. 1, no. 12, pp. 1023-1033, 1999.

[13] N. O. Kaakoush, N. Castaño-Rodríguez, H. M. Mitchell, and S. M. Man, "Global epidemiology of Campylobacter infection," Clinical Microbiology Reviews, vol. 28, no. 3, pp. 687720, 2015.

[14] H. L. Nielsen, T. Ejlertsen, J. Engberg, and H. Nielsen, "High incidence of Campylobacter concisus in gastroenteritis in North Jutland, Denmark: a population-based study," Clinical Microbiology and Infection, vol. 19, no. 5, pp. 445-450, 2013.

[15] R. Raman, R. Devaramane, G. Mukunda Jagadish, and S. Chowdaiah, "Various imaging manifestations of posterior reversible encephalopathy syndrome (PRES) on magnetic resonance imaging (MRI)," Polish Journal of Radiology, vol. 82, pp. 64-70, 2017.

[16] A. M. L. Quek, J. W. Britton, A. McKeon et al., "Autoimmune epilepsy," Archives of Neurology, vol. 69, no. 5, pp. 582-593, 2012.

[17] F. Graus, M. J. Titulaer, R. Balu et al., "A clinical approach to diagnosis of autoimmune encephalitis," The Lancet Neurology, vol. 15, no. 4, pp. 391-404, 2016.

[18] Z. Afzal, S. Kallumadanda, F. Wang, V. Hemmige, and D. Musher, "Acute febrile illness and complications due to murine typhus, Texas, USA 1,2," Emerging Infectious Diseases, vol. 23, no. 8, pp. 1268-1273, 2017.

[19] A. Ternhag, T. Asikainen, J. Giesecke, and K. Ekdahl, "A metaanalysis on the effects of antibiotic treatment on duration of symptoms caused by infection with Campylobacter species," Clinical Infectious Diseases, vol. 44, no. 5, pp. 696-700, 2007.

[20] Y. Yang, K. M. Feye, Z. Shi et al., "A historical review on antibiotic resistance of foodborne Campylobacter," Frontiers in Microbiology, vol. 10, p. 1509, 2019.

[21] A. Vojdani and E. Vojdani, "Reaction of antibodies to Campylobacter jejuni and cytolethal distending toxin B with tissues and food antigens," World Journal of Gastroenterology, vol. 25, no. 9, pp. 1050-1066, 2019. 